\title{
Kemerosotan Moral Di Kalangan Remaja: \\ Sebuah penelitian Mengenai Parenting Styles dan Pengajaran Adab
}

\author{
Diah Ningrum \\ Sekolah Menengah Islam Terpadu (SMIT) Al Marjan \\ Email:diah2025@yahoo.com
}

\begin{abstract}
Many reserach and surveys have been conducted to find out the types and levels of moral decadence among Indonesian youth. The objective of the current study is to show this phenomenon and to investigate whether parenting styles are related to the increased or decreased of incidences of moral decadence. The next focus is to relate the concept of Adab (an Islamic ethics) as defined by Al Ghazali to effective parenting styles that may reduce moral decadence among youth. The method used is qualitative method based on focus group discussion among parents in order to find out parenting styles applied in their families. In addition, document analysis is also used such as published official data, and reserach reports. The findings showed that there is relationship between parenting styles and moral decadence among youth. The researcher suggested that effective parenting styles should be related to teaching of Adab.
\end{abstract}

Key Words: moral decadence, youth, parenting styles, Adab.

Banyak penelitan dan survey yang telah dilakukan untuk mengetahui tipe-tipe dan level kemerosotan moral dikalangan remaja di Indonesia. Tujuan diadakannya penelitian sekarang ini adalah untuk menunjukan phenomena ini dan melakukan investigasi apakah parenting styles berkaitan dengan peningkatan atau pengurangan kasus kemerosotan moral. Fokus berikutnya adalah menghubungkan konsep Adab oleh Al-Ghazali dengan parenting styles yang efektif yang mungkin dapat mengurangi kemerosotan moral dikalangan remaja. Metode yang dipergunakan adalah metode penelitian kualitatif yang berdasarkan pada tehnik pengumpulan data focus group discussion dikalangan orang tua untuk menemukan pola parenting styles di rumah. Analisis dokumen juga dipergunakan seperti data-data yang dipublikasikan, dan laporan-laporan dari penelitian sebelumnya. Hasil menunjukkan bahwa terdapat hubungan antara parenting styles dan kemerosotan moral dikalangan remaja. Peneliti menyarankan bahwa parenting style yang efektif sebaiknya dihubungkan dengan pengajaran Adab.

Kata kunci: kemerosotan moral, remaja, parenting styles, Adab.

\section{Pendahuluan}

Menurut data Badan Kependudukan dan Keluarga Berencanan Nasional (BKKBN) tahun 2010, jumlah penduduk Indonesia adalah237.67 juta jiwa, dan populasi remaja adalah sekitar $26.67 \%$ dari jumlah tersebut. Usia yang dikategorikan remaja menurut BKKBN adalah antara usia 10-24 tahun (www.bkkbn.go.id) remaja yang dalam bahasa Inggris adalah adolesence, berasal dari bahasa Latin yaitu adolescare mempunyai arti tumbuh atau menjadi tumbuh dewasa (www.bkkbn.go.id). Tetapi bagaimanapun, pengertian remaja bukanlah terbatas 
pada pengertian itu saja. Melainkan mencakup kematangan emosional, sosial, dan fisik ( Hurlock, 1992 melalui www.ida i.or.id). Selanjutnya, World Health Organization (WHO) mengidentifikasikan remaja sebagai masa transisi sesudah masa kanak-kanak dan sebelum dewasa dengan usia sekitar 10 - 19 tahun (www.who.int). Masa remaja ini dianggap sebagai masa kritikal didalam fase kehidupan yang ditandai dengan pertumbuhan dan perubahan yang pesat. Perubahan ini mencakup faktor; fisik, alat reproduksi, sosial dan ekonom, kemandirian dan pencarian identitas diri (www.who.int).

Merujuk dari jumlah statistik remaja di Indonesia tersebut, maka tidaklah berlebihan jika dikatakan bahwa dengan jumlah persentase yang sebesar ini, akan memberikan dampak pada pembangunan dari aspek sosial, ekonomi maupun demografi di Indonesia (www.bkkbn.go.id). Selain itu perubahan apapun dalam pola pendidikan, sikap, usia menikah dan gaya hidup dikalangan remaja akan memberikan dampak pada lingkungan sosial dimanapun mereka berada (Mehta, Groenen, Roque, 1998). Hall (1904) melalui Byod and Bee (2005) menuliskan fase remaja didalam bukunya berjudul Adolescence. Dengan meminjam istilah dalam literatur bahasa Jerman, Hall (1904) melalui Byod dan Bee (2005) menyebut masa remaja sebagai fase "strurm und drang" (Storm dan stress), fase dimana remaja berusaha keras untuk menjadi seorang pribadi yang mandiri yang penuh dengan gejolak emosi bahkan kadang frustasi.

Tetapi sangatlah disayangkan apabila dalam proses pencarian jati diri dan menuju pribadi yang mandiri, para remaja sekarang ini terlibat dalam seks bebas, kekerasan, obatobatan, dan problem psikologis (Rachman, 2014). Dan Rachman (2014) juga menambahkan bahwa remaja modern sekarang punya kecenderungan dan permisif terhadap hubungan seks pranikah.Pusat data Badan Koordinasi Kependudukan Keluarga Berencana( BKKBN) tahun 2007 memaparkan hasil penelitian yang dilakukan oleh Damayanti untuk disertasinya pada Fakultas Ilmu Kesehatan Masyarakat, Universitas Indonesia menunjukkan bahwa dari 100 orang siswa, 5 diantaranya pernah melakukan hungan seks pranikah. 119 sekolah di lima daerah di Jakarta dan 8941 siswa sekolah menengah atas ikut ambil bagian dalam research ini. Selanjutnya survey yang dilakukan oleh BKKBN di 33 provinsi di Indonesia pada tahun 2008 menyebutkan bahwa sekitar $63 \%$ dari remaja terlibat dalam hubungan seks pranikah dan $21 \%$ remaja putri melakukan aborsi. Kemudian, data mengejutkan datang dari Dinas Kesehatan tahun 2009 menunjukkan bahwa remaja-remaja di empat kota besar yakni Medan, Jakarta Pusat, Bandung, dan Surabaya mempunyai teman yang berhubungan seks sebelum menikah sebesar $35.9 \%$. Sementara itu, para responden dalam data ini juga sudah melakukan hubungan seks pranikah sebesar $6.9 \%$ (www.bkkbn.go.id). Selain itu, survey yang diadakan oleh Komisi Nasional Perlindungan Anak pada bulan Januari - Juni 2010 di kota-kota besar di Indonesia yang melibatkan 4500 siswa sekolah pertama dan menengah memperlihatkan bahwa 62.75 siswa perempuan sudah tidak perawan lagi (Iskandar, 2010). Tentu saja phenomena ini sangatlah mengkhawatirkan karena pada pundak remaja inilah harapan kita sematkan kepada para remaja sebagai generasi penerus bangsa, dan harapan itu akan memudar apabila remaja terjerumus dalam pergaulan bebas dan seks bebas (www.kitadanbuahhati.com).

Tentu saja masalah kemerosotan moral dikalangan remaja saat ini tidaklah datang begitu saja. Menurut Fayumi dan Agus dalam Rachman (2014) menyebutkan bahwa pada masa transisi ini remaja mengalami ketidaktentuan dan ketidakpastian, serta banyak sekali mendapatkan godaan atau tarikan-tarikan untuk melakukan perbuatan yang tidak baik dan tidak jelas. Sang remaja dihadapkan pilihan untuk mengerjakan pekerjaan yang mengarah kepada kebaikan atau melakukan perbuatan keburukan yang dapat menjerumuskannya. Seorang remaja adalah seorang risk taker atau individu yang senang melakukan prilaku yang beresiko (www.kitadanbuahhati.com). Sehingga bagi remaja, seks bebas adalah sesuatu yang menantang. 
Prilaku berduaan, berpegangan tangan, bergandengan mesra, dan ciuman sudah menjadi hal biasa dikalangan remaja khususnya di kota-kota besar di Indonesia (Rachman, 2014). Sehingga prilaku berikutnya yang menantang adalah melakukan hubungan seks pranikah atau seks bebas.Prilaku remaja yang menganggap seks bebas merupakan suatu yang menantang merupakan contoh prilaku risk taking behavior (www.kitadanbuahhati.com). Selain itu lingkungan dan teman yang buruk juga menyebabkan remaja terjerumus dalam prilaku seks bebas. Apalagi jika remaja tersebut adalah anak bodoh, lemah akidah, mudah terombangambing, dan cepat terpengaruh ketika bergaul ('Ulwan, 2012). Kemajuan dan perkembangan teknologi juga dianggap memberikan kontribusi terhadap prilaku seks bebas. Anak-anak dan remaja dengan mudahnya mengakses situs-situs pornografi melalui smart phone, tab maupun ipad. Dampak dari pornorafi ini, sangatlah mengerikan yaitu dapat menyebabkan kerusakan otak yang sama seperti ketika mendapatkan kecelakaan dalam berkendaraan. Pornografi juga mendorong remaja untuk memuaskan hawa nafsunya melalui perkosaan atau seks bebas (www.islampos.com). Selanjutnya, faktor lain yang tidak kalah penting yang menyebabkan remaja melakukan seks bebas adalah orang tua. Remaja yang kurang kasih sayang dari orang tua, remaja yang tidah mendapatkan penerimaan dan pengakuan yang utuh dari orang tuanya, serta komunikasi yang buruk antara orang tua dan remaja cenderung terjerumus dalam prilaku seks bebas (www.kitadanbuahhati.com). Sehingga dengan kata lain, parenting style atau pola pengasuhan pada anak sangatlah penting untuk mencegah kemerosotan moral pada remaja.

Menurut pandangan psikologi barat, ada empat (4) tipe parenting styles yang dikemukakan oleh Baumrind di Santrock (2010); autoritarian parenting, autoritative parenting, neglectful parenting, dan indulgent parenting. Dalam teori ini, Baumrind mengkategorikan parenting styles berdasarkan 2 kategori utama yaitu yang pertama responsif yang mencangkup kehangatan, penerimaan, support, dan sensitivitas. Yang kedua, permintaan yang didalamnya ada unsur disiplin, permintaan yang sesuai dengan kematangan umur, dan kontrol (Carr, 2009).

Authoritarian parenting (restriktif parenting) adalah pola pengasuhan yang menekankan pada larangan, dan hukuman dimana dalam hal ini orang tua memaksakan anaknya untuk mengikuti perintah, serta menghargai pekerjaan dan usaha orang tua (Santrock, 2010). Orang tua yang menerapkan parenting style ini tinggi permintaanya tetapi tidak responsif terhadap kebutuhan psikologis anak-anaknya (Carr, 2009). Selanjutnya, kebalikan dari authoritarian parenting, authoritative parenting memotivasi anak-anaknya untuk menjadi anak yang mandiri tetapi masih mempunyai batasan-batasan dan kontrol dari orang tua (Santrock, 2010). Dalam pola pengasuhan ini, orang tua mempunya permintaan dan responsif yang tinggi. Hal ini ditunjukkan dengan memberikan bimbingan pada anak-anak dengan sikap yang baik. Mereka meletakkan standar yang tinggi dan menerapkan kontrol yang tegas jika bimbingan dari orang tua diperlukan. Orang tua ini juga memahami hak-hak individual anaknya dengan memberikan penjelasan setiap tindakan dan disiplin yang diterapkan di rumah. Setiap tindakan disiplin yang diambil lebih kepada tindakan supportive daripada memberikan hukuman. Selain itu komunikasi yang baik serta dua arah sangat dianjurkan (Carr, 2009).

Parenting style berikutnya adalah neglectful parenting (uninvolved parenting), dimana pada pola pengasuhan ini orang tua sama sekali tidak terlibat dalam pengasuhan anak-anaknya. Mereka menolak tanggung jawabnya sebagai orang tua dan perkembangan anak-anaknya (Carr, 2009). Selanjutnya, indulgent parenting adalah pola pengasuhan dimana orang tua sangat terlibat dalam kehidupan anak-anaknya tetapi tidak ada permintaan atau kontrol dari orang tua (Santrock, 2010). Anak dilepaskan tanpa pengawasan dan tidak memerlukan tanggung jawab dari setiap sikap dan tingkah laku perbuatan anak-anaknya ( Carr, 2009). 
Dari keempat parenting styles yang dikemukakan oleh Diana Baumrind, penelitian mengenai parenting styles pada anak umur 3-12 tahun menemukan bahwa anak-anak yang orang tuanya merupakan orang tua authoritative cendurung menjadi anak yang percaya diri, asertif, kompeten, mempunyai tenggang rasa, mudah bekerja sama, dan mature (matang) (Maccoby \& Martin 1983 di Carr 2009). Pada penelitian yang sama dikalangan remaja, ditemukan bahwa hasilnya konsisten dengan hasil penelitian anak-anak usia 3-12 yang mempunyai orang tua authoritative. Remaja dengan orang tua yang authoritative mempunyai prestasi dalam bidang akademik, punya percaya diri yang tinggi, dan punya daya tahan yang tinggi terhadap permasalahan. Remaja ini hanya sedikit mengalami masalah psikologis dan melakukan sedikit kesalahan.

Bagaimanakan pola pengasuhan atau parenting style dalam Islam? Didalam buku Tarbiyatul Aulad Fil Islam (Pendidikan Anak dalam Islam), 'Ulwan (2012) menyampaikan: “ Betapa besarnya tanggung jawab orang tua dalam mendidik anak-anaknya, dan mengancam mereka dengan azab yang besar jika mereka meninggalkan dan meremehkan atau berkhianat ". Allah SWT berfirman: "Hai orang-orang beriman, peliharalah dirimu dan keluargamu dari api neraka yang bahan bakarnya adalah manusia dan batu, penjaganya malaikat-malaikat yang kasar, keras, dan tidak mendurhakai Allah terhadap apa yang diperintahkan-Nya kepada mereka dan selalu mengerjakan yang diperintahkan (QS. At Tahrim (66): 6). Selain itu, di dalam Hadis, Rasulullah SAW banyak sekali menekankan pentingnya memberikan perhatian kepada anak-anak, berkewajiban melaksanakan urusannya, dan mendidiknya ('Ulwan, 2012). Salah satu diantaranya, Rasulullah SAW bersabda : "Seorang laki-laki adalah pemimpin didalam keluarganya dan ia bertanggung jawab terhadap keluarganya itu. Dan seorang wanita itu adalah pemimpin di dalam rumah suaminya dan ia bertanggung jawab terhadap apa-apa yang dipimpinnya itu..." (HR. Al-Bukhari dan Muslim).

Mengenai pentingnya peran orang tua dalam pendidikan anaknya juga ditekankan oleh Al-Ghazali melalui Nofal (1993) bahwa manusia dilahirkan sebagai tabula rasa, dan anak-anak mendapatkan personaliti, karakteristik, dan tingkah laku melalui lingkungannya, tempat dia berada. Keluarga mengajarkan bahasa, kebiasaan dan tradisi agama yang pengaruhnya tidak dapat dihindari. Oleh karena itu, menurut Al-Ghazali, Orang tualah yang punya tanggung jawab utama dalam mendidik anak-anaknya. Orang tua mendapatkan ganjaran apabila anaknya melakukan kebaikan, dan menanggung beban atas kesalahan mereka. Selanjutnya, Al-Ghazali juga menekankan pada pentingnya pembentukan karakter pada masa kanak-kanak. Pola pengasuhan yang baik akan memberikan karakter yang baik pada anak-anak dan membantu mereka hidup dijalan yang benar. Sedangkan pola pengasuhan yang salah akan mengacaukan karakternya dan susah untuk dibawa kembali ke jalan yang benar (Nofal, 1993).

Berdasar apa yang disampaikan di atas, jelaslah bahwa Islam sangat menitik beratkan pada pendidikan anak, dan meletakkan tanggung jawab yang utama kepada orang tua dalam mendidik anak-anaknya. Seperti yang sudah disebutkan di atas, ada dua pola pengasuhan atau parenting style dalam Islam menurut Al - Ghazali melalui Nofal, (1993), yaitu parenting style yang baik yang akan menhasilkan anak-anak yang memiliki karakter yang baik, sedangkan parenting style yang salah akan mengkasilkan anak yang kacau karakternya yang nantinya akan susah untuk ditarik kembali ke jalan yang benar. Menurut ' Ulwan (2012), parenting style yang baik adalah mendidik anak dengan keteladanan, mendidik dengan kebiasaan, mendidik dengan nasihat, mendidik dengan perhatian atau pengawasan, dan mendidik dengan hukuman. Apabilaparenting style ini diterapkan dalam keluarga maka tujuan pendidikan dalam Islam akan tercapai. Tujuan pendidikan dalam Islam salah satunya adalah membentuk manusia yang berkepribadian Islam (Rachman, 2012). Menurut Ahmad (2009), kepribadian Islami adalah kepribadian yang berhubungan dengan Sang Maha Pencipta, dimana manusia diciptakan untuk 
menunaikan ibadahnya kepada Allah SWT. Kemudian, kepribadian Islam adalah kepribadian yang sarat akan etika dan moral berdasarkan Al Qur'an dan pengajaran yang disampaikan oleh Nabi Muhammad SAW.

Etika atau moral dalam Islam dikenal dengan sebutan Adab yang berasal dari bahasa Arab (Al-Kaysi, 2000). Parenting style yang baik apabila diterapkan akan mampu menanamkan Adab al-Islam dalam keluarga. Adab al-Islam adalah kode prilaku sosial yang komprehensif, yang merupakan satu kesatuan tidak dapat dipisahkan dari kehidupan (Al-Kaysi, 2000). Adab al- Islam bersumberkan pada Al Qur'am dan Sunnah yang diajarkan oleh Nabi Muhammad SAW. Pengajaran Adab al-Islam dapat dilakukan dengan cara yang sudah dijelaskan Al Ghazali dalam Arshad dan Asmaa' (2003) yaitu; sosialisasi (al-Mukalatah), dan pembiasaan (al-I'tiyad), dan pembelajaran (al-Ta'allum). Sosialisasi adalah dasar dari proses pembentukan karakter pada masa kanak-kanak. Proses ini dapat dilakukan melalui observasi (alMushahadah), dan pendampingan (al- Musahabah). Orang tua yang telahterlebih dahulu mengamalkan kemudian baru mendampingi anaknya mengamalkan. Selanjutnya, pembiasaan (al- I'tiyad) dilakukan dengan disiplin. Sementara itu proses pembelajaran (al- Ta'allum) akan dimulai ketika anak berusia 7 tahun masa dimana anak mulai pendidikan formalnya. Pada pendidikan formal ini, anak belajar Al Qur'an dan Sunnah yang diajarkan oleh Nabi Muhammad SAW.

Melihat pentingnya parenting style dalam Islam dan pengajaran Adab kepada anak, maka penelitian ini dilakukan dengan tujuan untuk mengetahui sejauh mana peran orang tua dalam hal ini parenting style terhadap peningkatan atau pengurangan kasus - kasus kemerosotan moral dikalangan remaja. Kemudian, dari hasil penelitian parenting style tersebut, parenting style yang mana kah yang dianggap paling efektif untuk menanamkan Adab pada anak dan remaja.

\section{Metode Penelitian}

Pada penelitian sekarang ini, peneliti menggunakan metode penelitian kualitatif. Menurut Creswell (2008) dalam Raco (2010), " metode penelitian kualitatif sebagai suatu pendekatan atau penelusuran untuk mengeksplorasi dan memahami gejala sentral ". Sehingga data yang berasal dari penelitian kualitatif bukanlah berbentuk tabel atau angka-angka hasil pengukuran yang dianalisis secara statistik, melainkan data penelitian kualitatif merupaka informasi kenyataan yang terjadi di lapangan (Bungin, 2003 di Prastowo, 2010). Sedangkan tehnik pengumpulan data pada penelitian ini adalah focus group discussion atau wawancara kelompok terpusat. Focus group discussion (FGD) adalah kelompok tehnik khusus dalam tehnik pengumpulan data kualitatif. Hal ini berdasarkan pengelompokan yang dilakukan oleh Marshall dan Rossman dalam Prastowo (2010). Menurut Marshall dan Rossman, teknik pengumpulan data kualitatif dibagi menjadi kelompok tehnik inti yaitu berpartisipasi dilapangan, pengamatan secara langsung, wawancara mendalam, dan analisis dokumen serta materi budaya, dan kelompok tehnik khusus yakni focus group discussion atau wawancara kelompok terpusat, penelitian cerita dan sejarah hidup, foto, video, dan film, analisis interaksi, pengukuran tak terlihat, survey dan daftar pertanyaan, tes psikologis dan tehnik proyeksi, dan analis dilema. FGD dianggap merupakan tehnik pengumpulan data yang sesuai dalam penelitian ini karena dapat mengumpulkan data yang kaya akan detil informasi dan dari pandangan yang mendalam. Selain itu, FGD dianggap tehnik pengumpulan data yang tepat. Apabila dilakukan dengan benar, tehnik pengumpulan data ini akan menghasilkan suasana yang nyaman dimana partisipan dapat mengungkapkan jawaban dari hasil pemikirannya yang akan menambahkan makna pada jawaban yang diberikan (https;//assessment.aas.duke.edu/) 
Berikutnya, tehnik pengumpulan data pada penelitian ini juga adalah analisis dokumen baik berupa jurnal, laporan penelitian, dan data-data resmi yang dipublikasikan. Prastowo (2010) mengatakan bahwa untuk menghasilkan penelitian yang dapat dipercaya, maka tehnik pengmpulan data tidah hanya satu macam saja tetapi juga didukung dengan tehnik pengumpulan data yang lainnya. Dalam hal ini, tehnik pengumpulan data yang utama berasal dari FGD dan didukung oleh data yang lainnya melalui dokumen analisis.

Peneliti membagi peserta atau partisipan menjadi dua group kecil hal ini didasarkan pada Morgan (1996) bahwa group kecil lebih tepat jika topik yang dibicarakan menyentuh perasaan secara emosional dan memerlukan partisipasi yang tinggi dalam diskusi dari partisipan. Mengingat tema dari penelitian ini adalah mengenai kemerosotan moral dikalangan remaja, dimana para partisipan adalah orang tua, maka pembentukan group kecil ini dianggap tepat. Pembagian group berdasar status sosial ekonomi partisipan. Orang tua yang bekerja dengan orang tua yang tidak bekerja dengan latar belakang pendidikan yang sama bagi para peserta. Pemisahan (segmentation) tersebut berdasarkan ide segmentation yang disampaikan oleh FolchLyon dkk (1981) dalam Morgan (1996). Keuntungannya adalah dapat membangun berbagai macam dimensi yang memperkaya hasil penelitian secara keseluruhan, serta membuat partisipan menjadi nyaman karena semua partisipan mempunyai latar belakang yang sama. Sehingga diharapkan semua partisipan ikut aktif dalam diskusi dan tidak yang merasa tertinggal. Kruger (1994) mengatakan bahwa didalam FGD partisipan datang dari latarbelakang atau pengalaman yang hampir sama yang dikumpulkan bersama untuk mendiskusikan topik khusus sesuai dengan kepentingan peneliti.

Dua group diskusi dilaksanakan pada waktu yang berbeda, dengan topik dan pertanyaan yang sama dengan harapan memperoleh hasil diskusi yang lebih valid (https://assessment.aas.duke.edu). Sesuai dengan topik penelitian, peserta FGD adalah orang tua yang sudah mempunyai anak baik sebagai keluarga yang lengkap (ayah dan ibu) atau sebagai orang tua tunggal (single parent). Setiap peserta mempunyai anak 1-5 orang dengan rentang usia 1-21 tahun.

Pertanyaan yang diajukan berbentuk open-ended questions dimana memberikan kesempatan kepada partisipan untuk menjawab pertanyan berdasarkan berbagai macam pandangan, dan setiap partisipan dimotivasi untuk merespon jawaban berdasarkan situasi khusus para partisipan (Krueger, 1994).

\section{Hasil Penelitian}

\section{Deskripsi Focus Group}

Focus group discussion (FGD) diadakan sebanyak dua kali pada orang dan kelompok yang berbeda, tetapi dengan topik dan pertanyaan yang sama. Tujuannya adalah, peneliti ingin membandingkan jawaban dari kedua fokus group tersebut apakah ada perbedaan atau pandangan terhadap isu-isu yang dilontarkan. Selain itu juga untuk mendapatkan hasil yang lebih valid. Para partisipan dalam FGD adalah para orang tua yang mempunyai anak dari usia 121 tahun. FGD ini bertujuan untuk mengetahui sejauh mana peran orang tua dalam hal ini parenting styles yang diterapkan dikeluarga yang mungkin memberikan kontribusi pada meningkatnya kasus kemerosotan moral dikalangan remaja, dan juga untuk mengetahui sejauh mana peran parenting styles dalam pengajaran Adab kepada anak dan remaja,. 


\section{Hasil Focus Group}

\section{Pergaulan remaja sekarang ini}

Mayoritas peserta mengatakan bahwa pergaulan remaja sekarang ini sangat bebas, walaupun sebenarnya masih ada juga remaja yang sangat menjaga pergaulan dan tetap berpegang pada ajaran-ajaran agama. Tetapi jumlah itu lebih sedikit dibandingkan yang melakukan pergaulan bebas dan seks bebas sekarang ini. Remaja khususnya remaja Islam sekarang dianggap jauh dari ajaran-ajaran Agama Islam.

\section{Kasus-kasus kemerosotan moral}

Sebagian peserta mendapat informasi kasus-kasus seks bebas, hamil diluar nikah, dan aborsi melaui media televisi dan internet. Tetapi ada yang melihat langsung seperti remaja yang sedang nongkrong bersama teman-temannya pada malam hari sedang main kartu, minumminuman keras, dan pemakaian narkoba. Remaja yang kumpul bersama teman-temannya dimalam hari bukan hanya remaja laki-laki tetapi juga ada remaja perempuan. Bahkan, salah satu orang tua memergoki perbuatan seks bebas oleh remaja dimana seorang remaja perempuan digilir oleh beberapa remaja laki-laki. Kehamilan diluar nikah juga terjadi dilingkungan para orang tua peserta FGD.

\section{Faktor penyebab kemerosotan moral}

Empat faktor utama penyebab kemerosotan moral adalah lingkungan baik sekolah maupun tempat anak-anak bermain, kemajuan teknologi seperti internet dimana anak-anak dan remaja dengan mudah mengakses pornografi, sifat keingintahuan remaja, dan orang tua. Faktor orang tua sangat ditekankan disini karena jika orang tua menjalankan tugas dan tanggung jawab sebaik-baiknya dalam mendidik anak-anaknya, maka kejadian ini bisa diminimalkan. Orang tua dianggap tidak menanamkan nilai-nilai agama pada anaknya, tidak memberikan contoh yang baik, tidak adanya figur ayah yang baik dalam pengasuhan anak, dan tidak atau kurangnya kasih sayang orang tua kepada anaknya, serta buruknya komunikasi antara orang tua dan anak dianggap sebagai penyebab terjerumusnya remaja pada pergaulan bebas dan seks bebas. Jika orang tua mengamalkan nilai-nilai agama dalam keluarga dan mengajarkan pada anaknya, kasih sayang dan waktu yang berkualitas bersama anak-anaknya, keterlibatan seorang ayah dalam mendidik anaknya, serta adanya komunikasi yang baik diharapkan remaja mampu menangkal segala godaan yang datang dari luar.

\section{Parenting styles atau pola asuh yang efektif dalam mendidik anak-anak}

Peserta menyebutkan beberapa hal yang menyangkut parenting styles dalam mendidik anakanaknya supaya terhindar dari pergaulan bebas dan seks bebas. Parenting sytle yang digunakan hendaknya berupa komunikasi yang baik. Komunikasi yang baik dianggap sebagai satu cara untuk menanamkan ajaran-ajaran yang baik berdasarkan agama; Al Qur'am dan Sunnah, dan untuk menyampaikan hal-hal yang tidak baik yang bertentangan dengan ajaraan agama, normanorma keluarga dan masyarakat. Anak bukan hanya diberikan larangan tetapi juga diberikan penjelasan kenapa perbuatan itu dilarang, demikian juga dengan hal baik, anak juga dijelaskan mengapa diharuskan melakukan hal-hal yang baik. Selain itu, anak juga diberikan batasanbatasan mana yang boleh dilakukan, mana yang tidak. Kadang-kadang diperlukan ketegasan dalam memberikan batasan dan larangan. Batasan dan larangan akan diterima anak dengan baik jika disampaikan oleh orang tua secara baik. Orang tua diharapkan mempunyai skills untuk memahami dan mengerti perasaan anaknya, dalam hal ini tahu membaca situasi kapan saatnya berbicara dan kapan saatnya untuk menahan diri untuk menunggu waktu yang tepat. 
Keterbukaan dan kejujuran akan didapatkan jika komunikasi antara orang tua dan anak baik. Kepercayaan juga didapatkan oleh anak jika terbuka dan jujur kepada orang tuanya. Anak diperbolehkan untuk menyampaikan apa yang ada dipikiran dan perasaan tanpa merasa takut orang tuanya menjadi marah. Dan orang tua juga diharapkan menerima lapang dada dikoreksi oleh anaknya jika memang salah.

Kemudian, parenting styles juga harus melibatkan kedua orang tua baik ayah maupun ibu. Bukan hanya ibunya saja. Kedua orang tua memberikan contoh yang baik atau teladan melalui perkataan dan perbuatannya. Sehingga diharapkan anak-anak mencontoh perbuatan baik tersebut. Selanjutnya, pola asuh yang kompak antara ayah dan ibu dalam mendidik anakanaknya sangat penting sehingga didalam keluarga hanya ada satu suara. Penegakkan disiplin dalam keluarga juga dianggap penting.

\section{Pemahaman mengenai Adab}

Peserta dari FGD 1 dan 2 mengatakan bahwa Adab adalah norma-norma, etika, tata krama, moral, dan akhlak yang mengacu pada ajaran-ajaran yang diajarkan oleh Rasulullah SAW.

\section{Parenting styles yang efektif dalam mengajarkan Adab pada anak}

Peserta mengatakan parenting styles yang paling efektif dalam pengajaran Adab kepada anak-anaknya adalah dengan memberikan contoh, dan keteladanan. Jadi faktor figur orang tua yang mengajarkan dianggap penting. Selanjutnya pengajaran Adab juga memerlukan komunikasi yang baik. Komunikasi yang baik dipercaya dapat membantu orang tua menyampaikan atau menanamkan Adab kepada anaknya. Tentu saja cara penyampaian berbeda tergantung dari usia anak tersebut, apakah termasuk kategori anak atau remaja. Pujian diberikan jika anak mempunyai adab yang baik, teguran dengan kasih sayang dan nasehat ditunjukan jika anak melakukan hal-hal yang tidak baik.

\section{Pembahasan}

Phenomena pergaulan bebas dan seks bebas dikalangan remaja sangatlah mengkhawatirkan. Jika tidaklah berlebihan istilah " moral panik" akan dipergunakan untuk mendeskripsikan betapa buruknya pergaulan remaja sekarang ini. Istilah " moral panik “ diperkenalkan oleh Cohen (1972) melalui Parker dkk (2013) yang mendefinisikan sebagai kepanikan massa yang disebabkan oleh prilaku salah remaja. Prilaku remaja yang jauh dari ajaran-ajaran agama, dalam hal ini agama Islam seperti; seks bebas, hamil diluar nikah, aborsi, judi, minum-minuman keras, dan penggunaan narkoba merupakan beberapa contoh prilaku remaja yang meresahkan masyarakat umumnya, khusunya orang tua. Sifat remaja yang berani mengambil resiko (risk taker) atau faktor keingintahuan remaja disinyalir menjadi penyebab prilaku sumbang tersebut. Tetapi sifat remaja sebagai risk taker atau faktor keinginan tahu remaja bukanlah satu-satunya faktor yang menyebabkan kemerosotan moral dikalangan remaja, faktor lingkungan, kemajuan teknologi, serta orang tua yang tidak peduli dan tidak menanamkan ajaran-ajaran agama Islam kepada anaknya memberikan kontribusi terhadap permasalahan ini. Menurut Al Ghazali di Nofal ( 1993), lingkungan membentuk manusia, dan tujuan dari lingkungan adalah melaksanakan shari' $a$ atau hukum-hukum Islam dan tujuan daripada manusia adalah untuk mencapai kebahagian dengan mendekatkan diri Allah SWT. Tetapi lingkungan dapat berubah menjadi buruk atau lebih buruk dimana kekuatan individu tidak sebanding dengan kekuatan lingkungan. Merujuk pada apa yang telah disampaikan oleh Al-Ghazali di Nofal (1993), dapat dikatakan betapa besarnya pengaruh lingkungan terhadap anak dan remaja, hal ini konsisten dengan hasil yang di dapatkan dari FGD bahwa faktor lingkungan seperti 
sekolah dan tempat anak bermain dapat menjadi penyebab kerusakan moral pada anak. Lingkungan yang buruk akan menyebabkan anak menjadi buruk, sedangkan lingkungan yang baik akan menjadikan anak yang baik, yang pada hakikatnya tujuan dari lingkungan adalah melaksanakan shari'a.

Pada dasarnya, seorang anak cenderung akan memilih lingkungan yang baik tempat dia bergaul apabila dia mendapatkan bimbingan dari orang tua. Karena tugas dari orang tua adalah untuk mengawasi remaja didalam pergaulannya (Rachman, 2014). Sayangnya, banyak orang tua yang tidak peduli terhadap tugas dan tanggung jawabnya sehingga tidak menanamkan nilai-nilai agama kepada anak-anaknya. Komunikasi yang buruk antara orang tua dan anak dapat dijadikan indikasi betapa orang tua tidak menjalankan tugasnya sebagai orang tua sebaik-baiknya. Menurut 'Ulwan (2012), seorang anak yang tidak mendapatkan perhatian, kasih sayang, dan bimbingan orang tua layaknya seperti anak yatim, yang hidup terasing. Bahkan lebih parah karena akan meyebabkan kerusakan umat secara keseluruhan. Menarik untuk disimak bahwa berdasarkan hasil FGD, faktor ketiadaan figur ayah dalam mendidik anaknya juga dipercaya memperparah situasi permasalahan ini. Seorang ayah yang hidupnya juga bergelimangan dosa dan penyimpangan yang hanya mengikuti hawa nafsu saja akan menghasilkan anak yang tidak baik pula ('Ulwan, 2012). Sehingga berdasarkan hasil penelitian ini dapat dikatakan bahwa faktor orang tua juga disebut sebagai penyebab kemerosotan moral remaja sekarang ini. Untuk itu, hasil ini menjawab pertanyaan penelitian mengenai peran orang tua dalam peningkatan atau penurunan kemerosotan moral dikalangan remaja. Dalam penelitian ini, orang tua didapati menjadi faktor penyebab meningkatnya kasus kemerosotan moral dikalangan remaja.

Dikarenakan tugas dan tanggung jawab utama sebagai orang tua adalah mendidik anakanaknya, maka sudah seharusnya orang tua memilih pola pengasuhan atau parenting style yang tepat untuk menanamkan nilai-nilai agama kepada anak-anak mereka. Menurut Al-Ghazali dalam Nofal (1993), ada dua parenting style dalam Islam; parenting style yang baik dan parenting style yang tidak baik. Parenting style yang baik akan memberikan karakter yang baik pada anak-anak dan membantu mereka hidup dijalan yang benar. Sedangkan parenting style yang salah akan mengacaukan karakternya dan susah untuk dibawa kembali ke jalan yang benar (Nofal, 1993). Ciri parenting style yang baik dalam Islam adalah; mendidik dengan keteladanan, mendidik dengan kebiasaan, mendidik dengan nasihat, serta mendidik dengan perhatian atau pengawasan. Selain itu, berdasarkan hasil FGD, parenting style yang baik ditunjukan dengan komunikasi yang baik. Komunikasi yang baik akan memudahkan orang tua untuk menanamkan nilai-nilai agama kepada anaknya. Sehingga akan tercipta kejujuran dan saling percaya antara orang tua dan anak. Selanjutnya, parenting style yang baik melibatkan kedua belah pihak yakni kedua orang tua sehingga perkataan ketiadaan figur ayah dalam mendidik anaknya tidak akan ditemukan. Penegakan disiplin juga digunakan pada parenting style ini. Mengacu pada teori parenting style oleh Baumrind di santrock (2010), parenting style yang dideskripsikan oleh FGD adalah authoritative parenting dimana orang tua mempunyai permintaan dan responsif yang tinggi terhadap anak-anaknya. Hal ini ditunjukkan dengan memberikan bimbingan pada anakanak dengan sikap yang baik. Mereka meletakkan standar yang tinggi dan menerapkan kontrol yang tegas jika bimbingan dari orang tua diperlukan. Orang tua ini juga memahami hak-hak individual anaknya dengan memberikan penjelasan setiap tindakan dan disiplin yang diterapkan di rumah. Setiap tindakan disiplin yang diambil lebih kepada tindakan supportive daripada memberikan hukuman. Selain itu komunikasi yang baik serta dua arah sangat dianjurkan (Carr, 2009). Namun, parenting style dalam lslam lebih luas cakupan dibandingkan teori parenting ini, karena dalam islam parenting style yang digunakan bertujuan untuk mendapatkan kebahagian dan kebaikan kehidupan anak-anak di dunia dan akhirat. Yang menurut 'Ulwan (2012), “ seperti menyaksikan anak-anak tersebut bagaikan malaikat dalam hal kesucian rohnya, kejernihan jiwanya, kebersihan hatinya, dan ketaatan kepada perintah-perintah Rabbnya". 
Dan 'Ulwan (2012) melanjutkan, “ bahkan mereka akan menjadi teladan yang baik bagi orang lain dalam setiap kemuliaan, keutamaan, pengorbanan, akhlak, dan amal shalih “.

Berikutnya adalah pembahasan mengenai Adab. Pemahaman mengenai Adab dianggap penting dalam penelitian ini dengan maksud untuk melihat sejauh mana Adab diajarkan pada keluarga patisipan FGD. Adab menurut pemahamam partisipan adalah adalah norma-norma, etika, tata krama, moral, dan akhlak yang mengacu pada ajaran-ajaran yang diajarkan oleh Rasulullah SAW. Adab berasal dari bahasa arab yang artinya kebiasaan yang meliputi etika, tata cara bersikap yang diambil dari orang yang dianggap sebagai contoh (Gabrieli, 1960 dalam Al-Kaysi, 2000) . Dengan berkembangnya Agama Islam dijazirah Arab, istilah Adab mengalami perkembangan yakni menyangkut etika dan implikasi sosialnya. Sehingga Adab didefinisikan sebagai alat untuk mendapatkan sikap yang baik. Oleh karena itu, Adab al-Islam adalah cara berprilaku yang baik berdasarkan agama Islam. Yang tentu saja dalam hal ini, berdasarkan Al Qur'an dan Sunnah yang diajarkan oleh Nabi Muhammad SAW. Al-Ghazali dalam Nofal (1993) menyebutkan pentingnya pembentukan karakter anak pada masa kanakkanak. Pembentukan karakter dapat didefinisikan sebagai pengajaran Adab al-Islam pada anak. Oleh karena itu penting untuk dipahami bahwa pembentukan karakter tersebut hendaklah dengan cara yang efektif dan jelas (Al-Ghazali di Nofal, 1993).

Dari hasil FGD, ditemukan bahwa pengajaran Adab akan lebih efektif dengan memberikan contoh dan keteladanan. Hal inilah yang dilakukan oleh Rasulullah SAW dalam mengajarkan ajaran agama Islam kepada umatnya melalui contoh dan keteladanan. Memberikan contoh atau keteladanan pada anak adalah salah satu ciri yang terdapat pada parenting style dalam Islam (Islamic parenting). 'Ulwan (2012) mengatakan bahwa dengan memberikan keteladanan, orang tua telah menggunakan cara yang efektif dan berhasil dalam membentuk akhlak, mental, dan sosial anak. Dengan keteladanan, anak akan akan mengikuti tingkah laku atau akhlak orang tuanya baik disadari maupun tidak. Tidak hanya perbuatan melainkan juga perkataan ('Ulwan, 2012). Bandura (1996) dalam social learning theory mengatakan bahwa anak belajar melalui pengamatan. Anak-anak mengobservasi prilaku atau kebiasaan yang baru untuk mendapatkan ide bagaimana perbuatan tersebut dilakukan. Kemudian, informasi tersebut digunakan untuk membimbingnya berprilaku Selain itu berdasarkan hasil FGD, untuk menanamkan Adab al-Islam diperlukan komunikasi yang baik untuk menyampaikannya. Cara penyampaian hendaklah berbeda tergantung dari usia anak.

Al-Ghazali dalam Arshad dan Asmaa' (2003) menyampaikan bahwa ada 3 proses pengajaran Adab kepada anak sehingga Adab tersebut menjadi bagian dalam kehidupan anak, yaitu sosialisasi (al-Mukalatah), dan pembiasaan (al-I'tiyad), dan pembelajaran (al-Ta'allum). Sosialisasi adalah dasar dari proses pembentukan karakter pada masa kanak-kanak. Proses ini dapat dilakukan melalui observasi (al-Mushahadah), dan pendampingan (al- Musahabah). Orang tua yang telah terlebih dahulu mengamalkan kemudian baru mendampingi anaknya mengamalkan. Selanjutnya, pembiasaan (al- I'tiyad) dilakukan dengan disiplin. Ketika anak mendekati usia pendidikan formalnya pada usia 7 tahun, anak diajarkan Al Qur' an dan sunnah. Proses pembelajaran (al-Ta'allum) yang berlangsung pada periode ini dilakukan oleh orang tua dan guru. Untuk itu, parenting style yang memuat karakteristik seperti yang didapatkan pada hasil focus group dapat digunakan untuk mengajarkan adab pada anak dengan menggunakan 3 proses pengajaran yang disampaikan oleh Al-Ghazali dalam Arshad, Asmaa' dkk (2003).

\section{Kesimpulan dan Saran}

Berdasarkan hasil penelitian sekarang ini, seluruh pertanyaan penelitian sudah terjawab. Berdasarkan pengumpulan data dari focus group ditemukan bahwa memang terjadi kemerosotan moral dikalangan remaja di Indonesia. Remaja Indonesia sudah sangat jauh dari 
ajaran-ajaran agama. Prilaku menyimpang seperti pergaulan bebas dan seks bebas dianggap sudah biasa dikalangan remaja sekarang ini. Kasus-kasus seperti seks bebas, hamil diluar nikah, dan aborsi tidak hanya didapatkan melalui media tetapi juga terjadi dilingkungan para peserta FGD. Empat faktor utama yang menyebabkan kemerosotan moral adalah lingkungan baik sekolah maupun tempat anak-anak bermain, kemajuan teknologi seperti internet dimana anakanak dan remaja dengan mudah mengakses pornografi, sifat keingintahuan remaja, dan orang tua. Faktor orang tua dinilai penting dalam studi ini karena seperti apa yang dikatakan AlGhazali dalam Nofal (1993) Orang tualah yang punya tanggung jawab utama dalam mendidik anak-anaknya. Orang tua mendapatkan ganjaran apabila anaknya melakukan kebaikan, dan menanggung beban atas kesalahan mereka.

Memandang besarnya tanggung jawab orang tua terhadap pendidikan anaknya, sudah seharusnya orang tua mencari cara yang efektif dalam menanamkan nilai-nilai kebaikan kepada anaknya. Pola pengasuhan atau parenting style yang efektif yang dianggap dapat menghindari anak dan remaja khususnya dari pergaulan bebas dan seks bebas adalah parenting style yang menekankan pada komunikasi yang baik, komunikasi dua arah, antara orang tua kepada anak, dan anak kepada orang tua. Dengan komunikasi yang baik, diharapkan orang tua dapat mengajarkan nilai-nilai agama pada anak. Keterlibatan kedua orang tua dalam pengasuhan anaknya dinilai berdampak baik pada pertumbuhan anak. Selain itu, memberikan keteladanan yang baik pada anak, kejujuran dan kepercayaan pada anak juga merupakan karakteristik dari parenting style yang baik.

Pemahaman mengenai Adab dan parenting style yang tepat dalam rangka mengajarkan anak karakter yang baik sangat diperlukan oleh orang tua. Parenting style yang mengedepankan keteladanan, komunikasi dan kehadiran kedua orang tua dalam mengasuh anaknya dianggap efektif untuk mengajarkan anak Adab al-Islam. Adab al-Islam adalah tata krama, etika, sopan santun, dan akhlak yang berdasarkan Al Qur'an dan Sunnah yang disampaikan oleh Rasulullah SAW. Apabila parenting style yang efektif ini dikombinasikan dengan pengajaran Adab yang disampaikan oleh Al-Ghazali dalam Arshad, Asmaa' dkk (2003) maka diharapkan anak akan memiliki akhlakul karimah.

Saran-saran juga diperlukan untuk kepentingan penelitian pada topik yang sama dimasa depan. Penelitian sebaiknya juga dilakukan pada latar belakang pendidikan dan sosial ekonomi status yang berbeda, yaitu pada kelompok yang berpendidikan rendah dan berpenghasilan rendah. Dengan maksud untuk melihat pandangan atau tanggapan orang tua atas topik yang sama mengenai kemerosotan moral dikalangan remaja. Orang tua yang mempunyai pendidikan tinggi umumnya lebih sadar pada pola pengasuhan anaknya, sedangkan orang tua yang berpendidikan rendah kemungkinan kurang menyadari pentingnya pola pengasuhan yang tepat pada anaknya. Walaupun tidak ada kepastian bahwa orang tua yang berpenghasilan tinggi akan menjadi orang tua yang peduli pada pola pengasuhan anaknya dan ikut menanamkan nilai-nilai kebaikan pada anak, tetapi tetaplah menarik perhatian untuk melakukan penelitian dengan peserta diskusi dari kelompok berpenghasilan rendah untuk mengetahui sejauhmana pendapat dan pandangan mereka terhadap permasalahan ini.

\section{Bibliografi}

Al-Kaysi, I. M. (2000). Morals and Manners in Islam. Malaysia: Islamic Book Trust.

Arshad., Asmaa', M. (2003). A Comparative Analysis of Al-Ghazali and Miskawaih on Child

Education. Islamic Culture: an English Quarterly, 27(4), pp. 1-30. 
Byod, B., Bee, Helen. (2006). Lifespan Development. United States of America: Pearson Education Inc.

Carr, E. D. (2009). Perenting Style: Encyclopedia of the Life Course and Human Development. Vol1: Childhood and Adolescence. USA; Macmillan.

Iskandar, R. (2010). Impact of Modern Phylosophy on Young Indonesian Muslim Students. Paper dipresentasikan dalam Second ISTAC International Conference on Islamic Science and the Contemporary World: Islamic Science in Tertiary Education. International Institute of Islam Thought and Civilization International Islamic University Malaysia.

Krueger, R. A. (1994). Focus Group: a Practical Guide for Applied Research. (2nd Edn). USA: Sage Publication.

Morgan, D. L. (1996). Focus Groups. Annual Review of Sociology, 22, pp. 129-152.

Nofal, N. (1993). Al-Ghazali. Prospects: the Quarterly Review of Contemporary Education. Vol. XXIII, No 3/4, pp. 519-542.

Parker, L., Nilan, P. (2013). Routledge Contemporary Southeast Asia Series: Adolescents in Contemporary Indonesia. London \& New York: Routledge.

Prastowo, A. (2010). Menguasai Tehnik-Tehnik Koleksi Data Penelitian Kualitatif. Jogjakarta: Diva.

Raco, R. (2010). Metode Penelitian Kualitatif (2010). Jakarta: GrasindoSantrock, J. W. (2010) Child Development.. (12th Edn). New York: McGraw-Hill.

Rachman, F. M. (2012). Islamic Teen Parenting. Jakarta: Erlangga.

Saiyad, F. A. (2009). The Islamic Personality. Dalam Haque, A., \& Mohammed, Y. (Eds). Psychology of Personality. Singapore: Cengage Learning Asia Pte Ltd.

Santrock, J. W. (2010) Child Development.. (12th Edn). New York: McGraw-Hill.

'Ulwan, N. A. (2012). Tarbiyatul Aulad fii Islam (A. R. Hakim, Penerj). Solo: Penerbit Insan Kamil Solo.

\section{Artikel}

Bahayanya Kerusakan Otak Akibat Pornografi. Diunduh pada 16 Februari 2015, dari https://www.islampos.com/bahayanya-kerusakan-otak-akibat-pornografi-51108/.

Guidelines for Conducting a Focus Group. Diunduh pada 16 februari 2015, dari https://assessment.aas.duke.edu/.../How-to-conduct-a-focus-group.pdf.

BKKBN (Badan kependudukan Keluarga Berencana Nasional). Diunduh pada 11 Agustus 2010, dari http://www.bkkbn.go.id/Webs/DetailRubrik.php?myID=523.

Kajian Profil Penduduk Remaja (10-24 tahun): Ada Apa Dengan remaja?. Diunduh pada 9 Februari 2015, dari file://c./users/Dell/Downloads/kajian\%20\%profil\%20penduduk\%20remaja\%20(10\%2024\%20tahun)pdf.

Mehta, S., Groenen, R., Rouque, F. (1998). Adolescents in Changing Times: Issues and Perspectives for Adolescent Reproductive health in the ESCAP Region. Diunduh pada 11 Agustus 2010, dari http://www.unescap.org/esid/psis/population/icpd/sec7.asp.

Mengapa Remaja Kita Terjerumus Seks Bebas?. Diunduh pada 1 Februari 2015, dari www.kitadanbuahhati.com/article/mengapa-remaja-kita-terjerumus-seks-bebas.html.

Pedoman Pengelolaan Bina Keluarga remaja (BKR). Diunduh pada 1 Februari 2015, dari www.bkkbn.go.id. 
UNISIA, Vol. XXXVII No. 82 Januari 2015

Peran Pendidikan dalam Mengatasi Masalah Kesehatan Remaja. Diunduh pada 9 Februari 2015, dari idai.or.id/public-articles/seputar-kesehatan-anak/peran-pendidikan-dalam-mengatasikesehatan-remaja.html.

Policy Brief : Pusat Penelitian \& Pengembangan Kependudukan BKKBN. Seri I no. 6/pusduBKKBN/Desember 2011. Diunduh pada 9 Februari 2015, dari www.bkkbn.go.id.

Topics Adolescence. Diunduh pada 10 Februari 2015, dari www.who.int/maternal_child_adolescence/topics/adolescence/dev/en. 